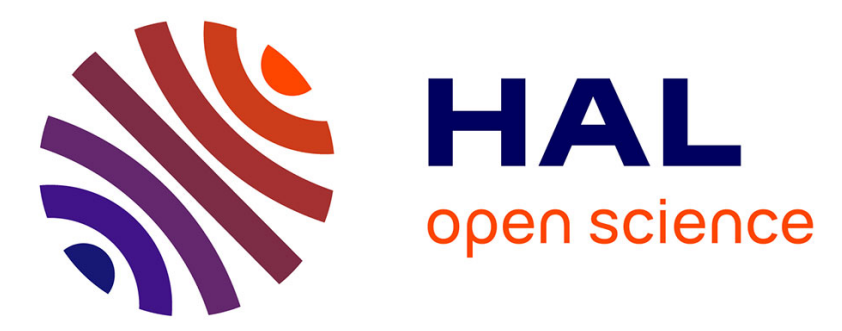

\title{
DEVELOPMENT OF THE ULTRASONIC HIGH TEMPERATURE BOLT STRESS MONITOR
}

\author{
S.-M. Zhu, J. Lu, M.-Z. Xiao, Y.-G. Wang, M.-A. Wei
}

\section{To cite this version:}

S.-M. Zhu, J. Lu, M.-Z. Xiao, Y.-G. Wang, M.-A. Wei. DEVELOPMENT OF THE ULTRASONIC HIGH TEMPERATURE BOLT STRESS MONITOR. Journal de Physique IV Proceedings, 1992, 02 (C1), pp.C1-923-C1-926. 10.1051/jp4:19921202 • jpa-00251168

\section{HAL Id: jpa-00251168 https://hal.science/jpa-00251168}

Submitted on 1 Jan 1992

HAL is a multi-disciplinary open access archive for the deposit and dissemination of scientific research documents, whether they are published or not. The documents may come from teaching and research institutions in France or abroad, or from public or private research centers.
L'archive ouverte pluridisciplinaire HAL, est destinée au dépôt et à la diffusion de documents scientifiques de niveau recherche, publiés ou non, émanant des établissements d'enseignement et de recherche français ou étrangers, des laboratoires publics ou privés. 


\title{
DEVELOPMENT OF THE ULTRASONIC HIGH TEMPERATURE BOLT STRESS MONITOR
}

\author{
S.-M. ZHU, J. LU, M.-Z. XIAO, Y.-G. WANG and M.-A. WEI \\ Institute of Acoustics, Tongji University, Shanghai 200092, P.R. China
}

\begin{abstract}
A high temperature bolt stress monitor, based on the testing of the Transit Time of Longitudinal wave and Shear Wave (TTLSW for short) and on the calculation of the stress through the established stress vs TTLSW equation, has been developed and tested. Lithium Niobate was used for piezoelectric material, gold or silver films were used for coupling material and clamping together method was used to install the transducer. Time interval averaging, zero crossing detect and several other techniques were used to improve the accuracy of TTLSW measurement. Using this method within the range of $30-360^{\circ} \mathrm{C}$, and $0-443 \mathrm{MPa}$ the accuracy of stress is better than $9.8 \mathrm{MPa}$.
\end{abstract}

Nous avons developé et éssaiye un moniteur à haute temperature de contrainte dans boulon. Son principe est la mesure du temps de transmission des ondes longitudinal et transversale (breivement TTLSW) et la calculation de contrainte par l'equation établie entre contrainte et TTLSW. Niobate de Lithium est utilise comme material piezoelectrique, feuille de l'or ou de l'argent sont utilisé comme matérial couplant, et le transducteur est instalé par la method de "pressés en ensemble". Moyenne des lintervales du temps, dEtection par le zero croissant et certains autres techniques sont utilisees pour améliorer la precision measure du TTLSW. Dans la region de 30 a $360^{\circ} \mathrm{C}$, cette methode a une precision de contrainte meilleur que $9.8 \mathrm{MPa}$.

The integrity behavior and life of a bolted joint depend a great deal upon the clamping force exerted by the bolts on that joint. Too high or little clamping force can lead to fatigue failure, damage or leaks, vibration loosening, slipping and cramping. As a result many efforts have been made to solve the problem.[1],[2],[3]. We have developed a system that tests the TTLSW and then calculates the stress from it. The influence of temperature within the range of $20-360^{\circ} \mathrm{C}$ is automatically compensated. This equipment not only can monitor the stress during its assembling, but also at high temperature and will alarm when the bolt stress has serious changes. This alarm can win some time for us to take emergency measures to avoid disasters.

Basically when temperature or stress changes, the length and velocity of that bolt would change, causing the changement of TTLSW. If we suppose that the change of transit time vs stress coefficient $\mathbf{k}_{\mathrm{l}}, \mathbf{k}_{\mathbf{s}}$ and the Young's modulus $\mathrm{E}$ are functions of temperature, and that the coefficient of velocity vs temperature $h_{1}, h_{s}$ and thermoexpansion coefficients are functions of 
stress $h_{1}(P), h_{s}(P)$ and $f(P)$.Then changement of TTLSW vs temperature and stress can be written as:

$$
\begin{aligned}
& \Delta t_{L}=\frac{2 l}{V_{L}}\left[k_{L}(\theta)+\frac{1}{E(\theta)}\right] \cdot P+\frac{2 L}{V_{L}}\left[\frac{h_{L}(P)}{V_{L}}+f(P)\right] \Delta \theta \\
& \Delta t_{s}=\frac{2 l}{V_{S}}\left[k_{S}(\theta)+\frac{1}{E(\theta)}\right] \cdot P+\frac{2 L}{V_{S}}\left[\frac{h_{S}(P)}{V_{S}}+f(P)\right] \triangle \theta
\end{aligned}
$$

In fact TTLSW also changes with the thickness of the coupling layer and length of the bolt, the changement of TTLSW vs stress also depends on the residue manufacturing stress, clamping length...so the real problem is very complicated. If we try to derive a TTLSW vs stress equation considering all of the above mentioned factors it would be very difficult if not impossible. We decided to build up an experiment system that can test the real bolt's TTLSW and stress (oil pressure of the stress exerting pump) under $30-360 \mathrm{C}, 0-443 \mathrm{MPa}$ and clamping distance $150 \mathrm{~mm}$, then derived the relation of TTLSW vs stress from the tested data.

Considering the transducer of the monitor has to work under high temperature and radiation continuosly, we used Lithium Niobate as piezoelectric material, gold or silver films for coupling material and clamping together method to install the transducer. Which can continuosly work un$\operatorname{der} 360^{\circ} \mathrm{C}$ and radiation for at least two years.

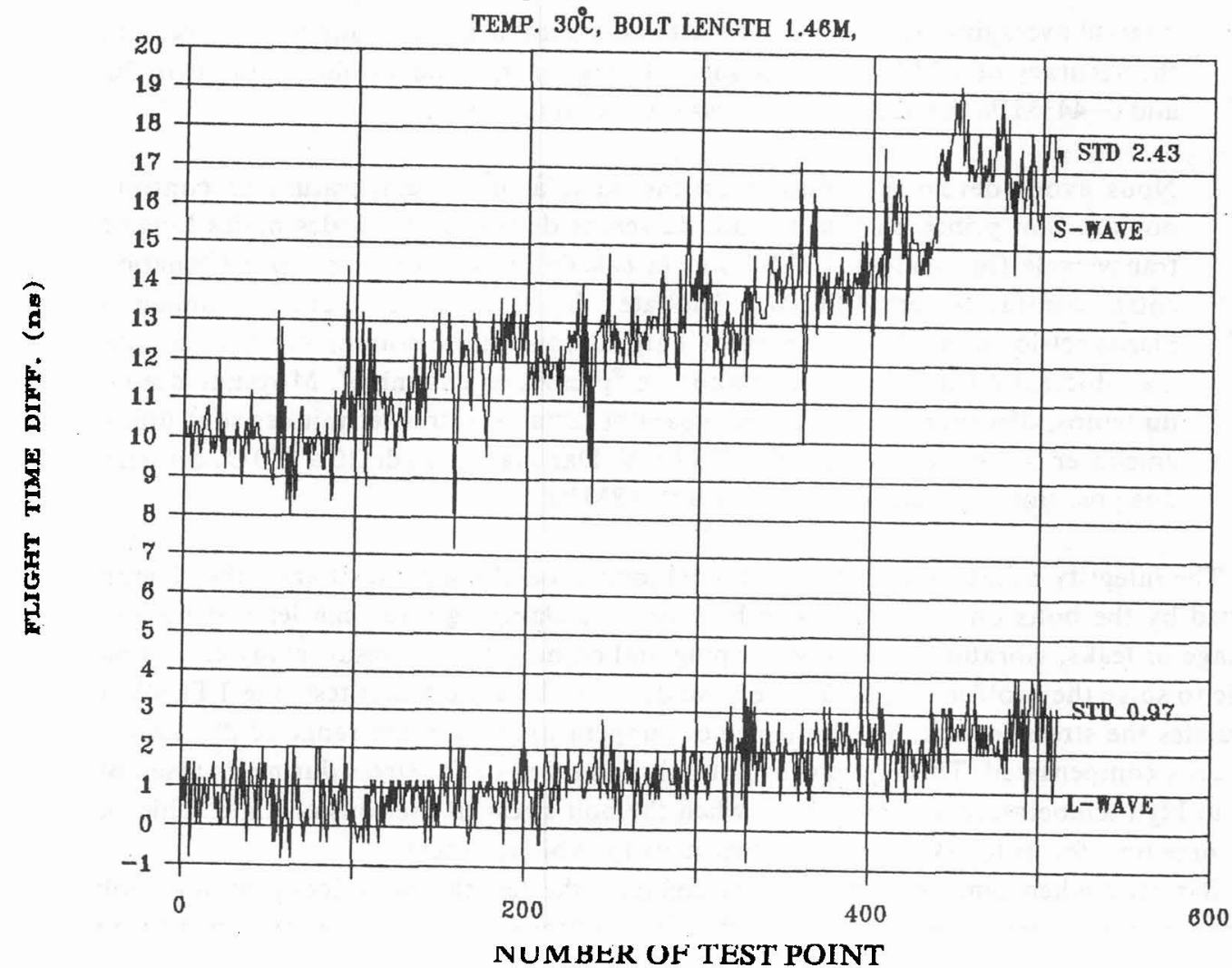

Pic 1. STABILITY OF THE SYSTEM 
High working frequency $(5 \mathrm{MHz})$, zero crossing detect, high emitting and receiving capability, high time clock frequency $(25 \mathrm{MHz})$, time interval averaging [4] and several other techniques were used to improve the accuracy of TTLSW measurement. At last the standard deviation of our equipment was only $0.82 \mathrm{~ns}$ and it was able to test the TTLSW of 1.64 Metre long bolts with TTSW more than 900 microseconds. Pic. 1 showed the result of the equipments stability test, 512 points of TTLSW on a 1.64 Metre long bolt were tested continuously, transit time of L-wave and $\mathrm{S}-$ wave increased synchronously and $\mathrm{S}$-wave increased quicker, because the temperature was rising, the standard deviation of $\mathrm{L}$-wave was only $0.92 \mathrm{~ns}$ which included the error due to temperature raise.

A High temperature TTLSW vs stress testing system was built to test the TTLSW vs stress within the real circumstances $\left(30^{\circ} \mathrm{C}-360^{\circ} \mathrm{C}, 0-443 \mathrm{MPa}\right.$, clamping length $\left.150 \mathrm{~mm}\right)$. Pic. 2 showed the main results. We can see the influence of temperature changement $30^{\circ} \mathrm{C}-360^{\circ} \mathrm{C}$ is 200 and 800 times bigger than the influence of $9.8 \mathrm{MPa}$ (the accuracy wanted). 2 .All of the tested points do not overlap. The TTLSW increases as the temperature or stress increases. This means TTLSW with temperature and stress has a strict one pair to one pair relation.

On the basis of the results mentioned above. We suppossed that all of the tested data fit a 2 variable equation of several orders, we used least square fit and tried orders of 2 to 5 to calculate those coefficients from the original tested data. After comparing the results calculated with different orders, we choosed the order of 3 and derived the relation of TTLSW vs stress as:

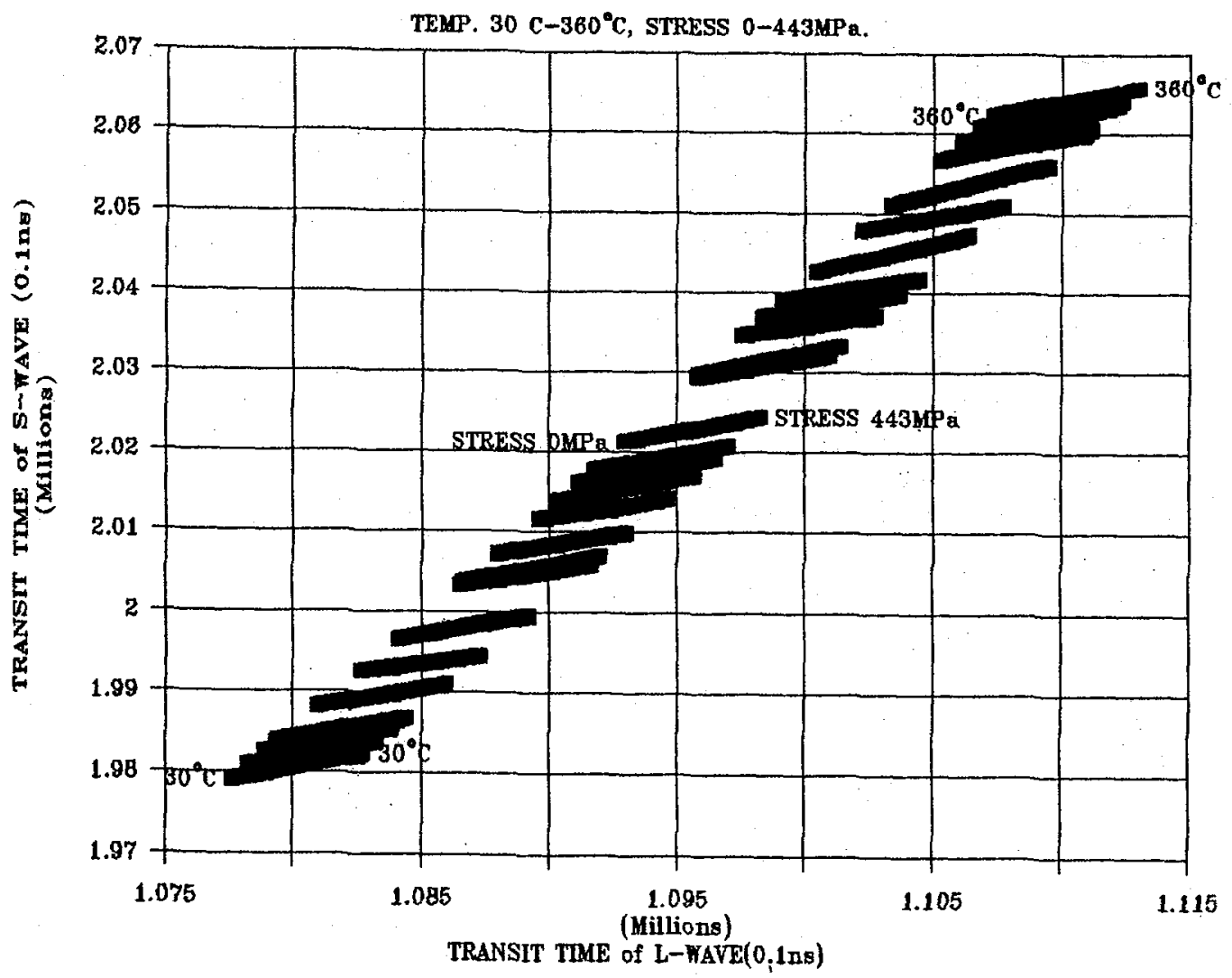

Pic 2. TRANSIT TIME OF L-WAVE vs S-WAVE 


$$
\hat{P}=\sum_{i=0}^{3} \sum_{i=0}^{3}\left(C_{i j}\right) \cdot t_{L}^{i} \cdot t_{s}^{\prime}
$$

where $P$ is the calculated stress, $t_{1}$ and $t_{s}$ are the transit time of $L$-wave and $S-$ wave. $C_{i j}$ are the sixteen coefficients: $C_{00}=-3036.0600, \quad C_{01}=-990.1270, \quad C_{02}=-45.5826, \quad C_{03}=0.0804$, $\mathrm{C}_{10}=1388.8680, \quad \mathrm{C}_{11}=342.7626, \quad \mathrm{C}_{12}=5.0965, \quad \mathrm{C}_{13}=-0.140382, \quad \mathrm{C}_{20}=-241.3629$, $C_{21}=-34.9397, \quad C_{22}=0.522132, \quad C_{23}=.0031775, \quad C_{30}=15.76011, \quad C_{31}=0.580279$, $\mathrm{C}_{32}=-0.0253915, \mathrm{C}_{33}=.00016054$

We stored this equation in the Rom of our Intellegent High Temp. Bolt Stress Monitor, it tests the TTLSW and directly calculates the stress. Measurements prooved that within the range of temperature $0-360^{\circ} \mathrm{C}$ and stress $0-443 \mathrm{MPa}$ accuracy of the monitor is better than $9.8 \mathrm{MPa}$.

The advantage of this method is: 1.In the experiment period it only requires to measure the TTLSW accurately and avoids the difficulty of measuring the temperature and other coefficients accurately. It is not necessary to control the temperature accurately. The numerical calculation by the computer solved all of the sophisticated influences in one shot. if we try to solve these influences seperately, we not only have to measure these coefficients and study their relations with temperature or stress, which is very hard to deal with, but also have the problem that every coefficient would bring in some error and the total of these errors would be greater than that of our method.

* This work is supported by China's Nuclear Safety Burea.

\section{REFERENCES}

(1) John H.Bickford,"Advances in bolting Technology",Nuclear Engineering and Design.Vo1.90,No.3,P307-315.

[2] J.H.Bickford,"Using Ultrasonic to measure the residual tension in bolts,"Experimental Techniques, 1988,No.11,P3s-5s.

(3) J.R.Winter,"Use of an Ultrasonic Extensometer to determine the variations in the assembly bolt loads of a problem industrial flange,"Experimental Techniques",1988,No.11,P6s-11s.

(4) J.DAindow and R.C.Chivers,"The optimization of electronic precision in ultrasonic velocity measurements: a comparison of the time interval averaging and sing around methods", JASA,P1833-1837,73,1983. 